Analysis on the Training Mode of Chinese Minority Language and
Literature Talents

\author{
Min Gong \\ Faculty of Chinese Language and Literature, Northwest University for Nationalities, Lanzhou 730030, Gansu, China \\ Email: 2425862044@qq.com
}

\begin{abstract}
Minority language and literature education has a very important position in college education, and it is the need for the inheritance of Chinese national culture. Minority language and literature talents have played a role in protecting and propagating minority culture. Therefore, China has always attached importance to the training of minority language and literature talents. Under the background of marketization in the new era, colleges and universities are facing new challenges in cultivating minority language and literature talents. How to enable minority language and literature talents to have their own seats in the fierce market competition will require some ethnic minority language and literature talents to have their own seats. Issues that need to be considered urgently in professional colleges and universities. This article will analyze and discuss the training mode of minority language and literature talents in Chinese universities from the perspective of focusing on practice, ensuring employment and keeping pace with the times when training minority language and literature talents.
\end{abstract}

Keywords: minority language and literature talents, training, mode

China is a multi-ethnic country, and the ethnic minorities have created a colorful and splendid culture in more than 5,000 years of Chinese history. With the advent of the era of integrated economy, the language and culture of ethnic minorities are facing serious impacts. More and more ethnic minorities' young generations have stepped out of their original cultural context, and more and more ethnic minority cultural heritages have been forgotten and obliterated. In order to protect the culture of ethnic minorities, the state vigorously advocates the development of ethnic minority education, culture and art, tourism and other industries. In terms of education, investment in minority subjects has been increased. Minority language and literature majors have shown an increasing trend in recent years. By 2021, there will be 30 or 40 colleges and universities offering minority language and culture majors, and the number of minorities' majors will increase. It brings great benefits to the protection of ethnic minority culture, but it does not guarantee the growth and stability of the source of ethnic minority language and literature majors. Therefore, colleges and universities should also pay attention to the training mode of ethnic minority language and literature talents.

The current minority language and literature talent training mode mainly teaches students systematic knowledge of national language and literature, and provides teaching, research, editing, translation, and news related to minority languages, writings, literature, and literature for minority education and cultural departments and related units. , Literary creation and other fields. Under the new social development situation, the original training mode of ethnic minority language and literature talents will not bring major changes to the development prospects of ethnic minority cultures. On the contrary, the inheritance of ethnic minority cultures has always been in a marginalized position. With the rapid changes in the current era, the training of ethnic minority language and cultural talents cannot stick to the old mode, but needs to innovate and develop on the basis of social needs, and establish a mode that is more adapted to the needs of the times. In the sense, it has been inherited and carried forward.

\title{
1. From theory to practice
}

The training of ethnic minority language and literature talents is the same as other disciplines. Ultimately, it should be practice-oriented. Professional theoretical knowledge is the foundation and fundamental. However, theoretical knowledge alone cannot guarantee their competence in work. Talents in the new era are even more important. Pay attention to the cultivation of ability. Only on the basis of mastering the theoretical knowledge, through continuous practice and experience, can the knowledge be truly applied to the work and become a part of the students' own work ability. The basic principle of minority language and literature talent training is to start with theoretical knowledge and achieve the ultimate goal of training practical ability. From the perspective of the particularity of the discipline, the training practice of minority language and literature talents should improve the students' national language application level and practical application ability. 


\subsection{Practice to increase oral conversation ability}

Language is an important feature of the human community and an important tool for communication, expression, and recording. Under normal circumstances, each nation has its own national language, but as the nation gradually merges and the world is increasingly connected, the use of language has become more concentrated. The use of minority languages is relatively small and can only be circulated within the local ethnic group. If students want to truly master the minority languages, language practice is indispensable. In traditional teaching, the school should provide students with practical classrooms to the greatest extent. For example, Yunnan Nationalities University and Nankai University have jointly developed the "Yunnan Minority Language Database" and phonetic laboratory, which provides students with convenient conditions for language conversation training.

In addition to adding sufficient language practice teaching to school teaching, it is also necessary to go to the gathering areas of ethnic minorities and communicate with local native speakers. The school can arrange a certain amount of time to lead students into ethnic minority areas for visits, learning and experience. Students can have a dialogue with locals in the real minority language context, so as to have a deeper understanding of local folk culture and at the same time enable students to get effective Spoken language practice has rapidly improved the language level of ethnic minorities.

\subsection{Create job and internship opportunities}

The training of ethnic minority language and literature talents is not only about mastering a minority language, but also about having a deep understanding of the culture and history of the ethnic minority you are learning. The most important thing in the cultivation of minority language and literature talents is the cultivation of practical work ability. The learning in the school theoretical knowledge classroom is not enough to cope with the changing working environment and types in the future. Therefore, the school should focus on communication and cooperation with the society, strengthen the relationship between government agencies, minority schools, and social institutions related to student employment, and establish channels for students to practice internships during the school.

The school can cooperate with the government and news departments to provide internship channels for students in the research, editing, and translation of ethnic minority language and literature in the government and news departments; it can also send students to minority groups by supporting education in ethnic minority mountainous areas. Ethnic schools participate in teaching and internship activities; they can also cooperate with enterprises related to ethnic minority culture to arrange for students to carry out related internship activities.

Through internships, students can accumulate practical work experience, build up confidence and courage to enter society in the future, become more handy in future work, and contribute to the work of ethnic minority languages and cultures.

\section{Face the market to ensure employment}

The ultimate goal of the minority language and literature major is to deliver the required high-quality applied minority language and literature talents to the society. Therefore, in the training mode of minority language and literature talents in colleges and universities, special attention should be paid to the actual demand for talents in minority areas. In recent years, the state has attached great importance to promoting the traditional culture of ethnic minorities. On this basis, many ethnic minority regions have actively developed ethnic cultural and artistic industries and tourism industries. On this basis, the market's demand for minority language and literature talents is more specific and professional, which puts forward higher requirements for the training of minority language and literature talents in colleges and universities.

\subsection{Based on the needs of traditional employers}

The needs of traditional employers for minority language and literature talents are mainly in minority government departments, education and culture departments, and some related units. Graduates can be engaged in the teaching, research, editing, translation, journalism and literary creation related to ethnic minority languages, writings, literature, and literature in relevant units. Graduates are required to be proficient in ethnic minority languages and possess historical and cultural skills. Pedagogy, journalism, administrative management and other related knowledge, with literary creation and practical working ability. The needs of traditional employers are the foundation of the training of ethnic minority language and cultural talents. First, ensure that students have the relevant professional qualities and abilities to meet the needs of elementary and secondary education in ethnic minority areas, news dissemination in ethnic minority areas, and the inheritance of ethnic minority cultures. In this way, on the one hand, it ensures that the traditional culture of ethnic minorities will be passed on, and on the other hand, it has also confirmed the importance of training ethnic minority language and literature talents in colleges and universities. 


\subsection{Demand for talents in the development of emerging industries}

As the country attaches great importance to the inheritance of ethnic minority cultures, some emerging ethnic minority related industries have sprung up, especially ethnic minority culture and art related industries, attracting a large number of fans who pay attention to folk art and culture, as well as tourism in ethnic minority areas. The industry is booming, attracting a large number of tourists who are interested in the customs of ethnic minorities. The prosperity of minority-related industries has followed with the demand for a large number of minority language and literature talents. In the fierce market competition environment, ethnic minority language and literature talents not only need to be proficient in ethnic minority languages and related subjects and cultural knowledge, but also need to master Internet technology, business, economics, psychology, copywriting and other aspects of knowledge and ability to adapt to the market Enterprise development requirements in an economic environment. The training mode of minority language and literature talents in colleges and universities needs to meet the standards of relevant enterprises for talents, and certain adjustments and additions should be made to the teaching content and practical content, so as to cultivate the mixed minority language and literature talents of the times. If the traditional minority culture, education and culture department is the basic channel for inheriting minority culture, then the emerging minority cultural enterprises bring economic benefits, but also give the minority culture the opportunity to shine, college minority language and literature majors It is necessary to seize the opportunity to maintain a high degree of communication with relevant industry platforms to form a point-to-point training mode for ethnic minority language and literature talents.

\section{Keep an eye on the society and advancing with the times}

Minority culture has never been an isolated existence. It needs not only the inheritance and continuation of its own ethnic group, but also more people's attention, appreciation and research. In the process of training minority language and literature talents, colleges and universities should not Focusing on the local areas of ethnic minorities, we should also look at the value of ethnic minority languages and literature in the overall social environment. In the teaching mode of ethnic minority language and literature, the integration of other disciplines and ethnic minority languages and literature should be strengthened. At the same time, the Han nationality culture and the national culture of other countries in the world should be increased to realize the minority language and literature talents. Only when national cultural knowledge is in line with the outside world can it be more conducive to the relevant ethnic minority cultural propaganda work.

With the rapid development of science and technology in the world today, electronic information technology is widely used, and the world is gradually showing a trend of integration. The changes brought about by science and technology have made the whole world change with each passing day. Under such historical trends, ethnic minority language and literature cannot be regarded as a traditional cultural discipline. In addition to being detached, it is not only affected by the development of the times, but also ushered in new development opportunities. The minority language and literature majors in colleges and universities should cultivate more outstanding talents, so that the minority language and literature majors can be expanded and developed. , We must not be complacent, but follow the footsteps of the times, carry forward the spirit of innovation and reform, and develop more new education modes that meet the needs of the times.

The development of the minority language and literature major has not been smooth sailing. In some ethnic colleges and universities, there have been more or less unstable student sources and unsatisfactory employment rates in different periods, which will affect the subsequent admissions of minority language and literature majors. And talent training. Under such circumstances, relevant colleges and universities need to broaden their thinking, conduct investigations on ethnic minority areas and related employers, conduct in-depth analysis of the needs of the social era, continue to develop and innovate, and establish talent training that conforms to the characteristics of ethnic minority education and the laws of development of the times. mode. First of all, the school-running mode should be integrated with social needs. The school and the government of ethnic minority regions can adopt a joint school mode, so that the school can better understand the current situation of minority language and literature talents in a timely manner, and achieve one-stop education and employment; In the teaching mode, we adopt a classified teaching method for students with different employment directions, and divide professional courses except languages in a targeted manner; in addition, in the learning mode, we adhere to the road of combining professional knowledge and practice to increase practical learning for students Classroom and work placement opportunities.

Minority culture has endured a great impact in the modern cultural trend, but on the other hand, it has also attracted the attention of the state and relevant departments, and increased investment in the inheritance of ethnic minority culture. In major colleges and universities, minority languages The cultivation of literary talents has a long way to go, and it has played a significant role in promoting the cultural development and economic construction of ethnic minority areas. Therefore, relevant colleges and universities are actively exploring the teaching mode of ethnic minority language and literature majors 
to implement the state's requirements for the protection of ethnic minority cultures. Culture is priceless, but the future life planning of ethnic minority language and literature professionals must be based on reality. While teaching ethnic minority language and cultural knowledge, schools must focus on students' practical application ability, and strive to combine theory with practice to provide students with better Many oral conversation practice environments and work internship opportunities train students to become compound talents needed by society, adapt to work in traditional minority units, and have the ability to experience in the market economy wave. The development of the times has entered an acceleration mode, and the inheritance of ethnic minority cultures is also facing new opportunities and challenges in the new era. The training of ethnic minority language and cultural talents must advance with the times, and continuous innovation and reform to cultivate professional talents that meet the needs of the times.

\section{References}

[1] He Shaoying, He Guanghan. Exploration and practice of the reform of Chinese minority language and literature talent training mode [J]. Journal of Yunnan Nationalities University: Philosophy and Social Sciences Edition, 2014, 031(006):151-156.

[2] Lou Xiaoyue. A Brief Talk on Chinese Minority Languages and Cultures and Their Inheritance[J]. Journal of Northwest Second Nationalities University, 2006 (03): 39-41.

[3] Yang Lang. The integrated development of ethnic minority language and literature and Chinese language and literature [J]. Journal of Jiamusi Vocational College, 2018 (04): 340-341.

[4] Guo Changshun. Multi-ethnic literature education: the integration and development of minority language and literature and Chinese language and literature [J]. Guizhou Ethnic Studies, 2016, 37 (09): 152-155.

[5] Li Jing. Research on the training strategy of ethnic minority language and literature talents [J]. Chizi (mid-early), 2017 (07): 245.

[6] Wang Ying. Analysis of the current situation of ethnic trilingual talent training in Xinjiang based on language economics [J]. Campus English, 2016 (29): 59-60.

[7] Tuoya, Lin Feng, Zhu Jianping. Multicultural teaching design in the training of high-level ethnic minority talents [J]. China National Education, 2010 (01): 22-24.

[8] Peng Xiaoling. Research and Practice on Phonetic Teaching of Modern Chinese Courses for Minority Languages and Literature Majors [J]. Academy, 2016 (02): 61-63.

[9] Kang Zhongde. Thoughts on the development of ethnic language disciplines_— Taking Guangxi University for Nationalities as an example [J]. Theoretical Observation, 2013 (04): 91-92.

[10] Liu Li. Research on the reform of the training mode of ethnic minority innovative talents in my country [J]. Journal of Baoji University of Arts and Sciences: Social Science Edition, 2017, 037 (002): 72-74. 